\title{
Late-onset junctional epidermolysis bullosa
}

INSERM

\section{Source}

INSERM. (1999). Orphanet: an online rare disease and orphan drug data base. Late-onset junctional epidermolysis bullosa. ORPHA:79406

Late-onset junctional epidermolysis bullosa is a subtype of junctional epidermolysis bullosa (JEB, see this term) occurring in childhood or young adulthood. 